\title{
Hereditary Papillary Renal Cell Carcinoma
}

National Cancer Institute

\section{Source}

National Cancer Institute. Hereditary Papillary Renal Cell Carcinoma. NCI Thesaurus.

Code C9222.

A familial carcinoma inherited in an autosomal dominant trait. It is characterized by the development of multiple, bilateral papillary renal cell carcinomas. The carcinomas range from microscopic lesions to clinically symptomatic tumors. It is associated with activating mutations of the MET oncogene. 